\title{
Intersecting culture, values and transformation in shaping an integrated ethnic identity within a diastratically variated society: Employing South Africa as a case study
}

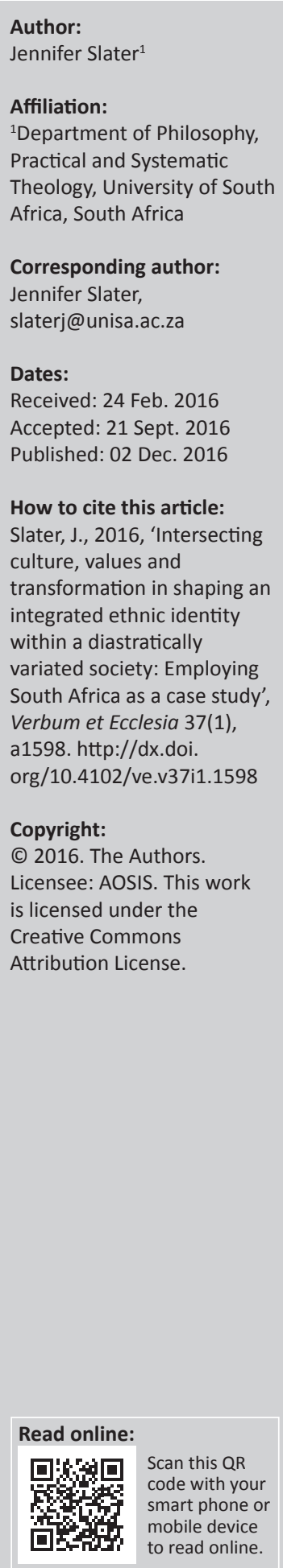

This article intersects various human diversities through the lens of Christian beliefs and practices as presented in Galatians 3:28. It sets out to identify some of the diastratic diverse factors that influence and shape the distinct socio-economic and cultural environments of the South African arrangement. The amalgam of Christian beliefs, together with cross-cultural practices and philosophical configurations, constitutes a wide range of worldviews that counter the formation of national unity and identity. By examining issues such as diversity and specifically diastratic diversity, as well as inclusiveness as the elixir to bring about national unity, it offers ways of embracing egalitarian ethics to bring about an integrated national identity. This article focuses attention on how value-transformation can be instrumental in the formation of national identity. As the demographics in South Africa are still dualistically designed, boundaries such as male and female, black or white, rich and poor, local or foreign, indigenous and alien, the study takes cognisance of these differences so as to bring all people into the equation of being human by accommodating multiple shades of skin colours, gender, social, cultural and ethnic variations into a diastratic unity. The article draws on how the composition of the Jesus Movement and early Christians, when St Paul, specifically in Galatians 3:28 dealt with diastratic diversity while establishing a Christian identity in antiquity.

Intradisciplinary and/or interdisciplinary implications: The approach to the article is multidisciplinary in the sense that it puts the contextual socio-economic and cultural South African problem of diastratic diversity under the searchlight of biblical, theological, ethical, sociological and constitutional specialities. It scrutinises the contemporary societal disorder of antagonism in the light of the early Christian values of inclusiveness and respect for human dignity so as to develop a sense of national cohesiveness that transcends differences and division. It proposes the cultivation of an inclusive diversity consciousness as a pastoral realisation that diversity is positive and necessary for healthy national building.

\section{Introduction}

Despite the fact that much credit had been given to the most progressive constitution that South Africa had devised and the celebration of a Bill of Rights, it can be argued that since the provision and implementation of human rights, new visible and invisible prejudices and divisions have emerged in post-apartheid South African society. Social expressions such as gender violence and inequality, xenophobia, homophobia, corruption, blatant poverty, fraudulent leadership and the abuse of freedom have emerged as new exclusivities. The question can be asked whether perhaps the granting of human rights, and in particular equality rights, disturbed the previous disparities and imbalances in such a manner that the creation of new scenarios brought about unfamiliar forms of 'social revolutionaries' for which people were quite ill prepared.

This article not only explores specifically the concept diastratic diversity in the post-apartheid South Africa but also draws lessons from the Jesus Movement, Christianity in antiquity, and how they dealt with diastratic diversity. It also ascertains the validity and value of diversity as a national imperative towards shaping a national and an integrated ethnic identity within a diastratically variated South African society. The article discerns how the very early Christians, members of the Jesus Movement, under the spiritual formation of St Paul used the characteristic of inclusiveness towards creating diastratic unity in a diastratic divergent society where cultural, racial, gender and social alterity formed part of the order of the day. While 'sameness' appears to be the primary force that consolidates a cohesive national identity, this article proposes that 
'alterity' within diastratic unity appears to be comprehensively more inclusive than the idea of unity in diversity. The article intends to raise consciousness about the capacity of 'inclusiveness of diversity' in the effort to positively build a national identity. To establish an inclusive culture implies going beyond awareness and knowledge as this is not enough to truly realise transformation and thus behavioural change.

\section{The concepts: Diastratic and a diastratically divergent society}

The South African society can be labelled as 'diastratically divergent' because of the diastratically variated elements that constitute the unique nature of the South African people. To create a diastratically integrated ethnic identity within a diastratically variated society implies that cognisance needs to be taken of all the ingredients of the plurifactorial dimensions of social, cultural, economic, gender, political, religious and class variations present in the society. It proposes the formation of a new ethnic identity that embraces the great variety of diastratic variances present in all the different features of the South African sociological, economical, political and cultural context. Since a diastratic integrated structure encourages the relativisation of differences, diastratic solidarity is enabled by the civilised implementation of human rights and values that inculcate attitudes that cut across diversity and by so doing establish diastratic unity and identity. Diastratic integration possesses the potential to embrace alterity and diversity in all its forms and even hold it in balance.

The term 'diastratic' is generally used in the architecture of language where there are dimensions of variations. 'On a diastratic dimension', according to Peter Auer and Jurgen (2010):

\footnotetext{
a language can co-vary with many different social factors. Besides social class, the main social factors which intervene to determine diastratic variation are age, sex or, better, gender (the sex of a person as reflected in social position, status, and role and their attributes) ethnically and social network. In many societies, membership in social and professional groups or religious faith can also be relevant factors of language differentiation. (p. 233)
}

In diastratic variation, social class is by no means a clear-cut and indisputable category. Social class is a plurifactual concept that includes various mixtures of ingredients such as education, occupation, income, attributes, lifestyle and social networks: namely a structured set of social relations connecting a person and people with whom this person interacts (Auer \& Jurgen 2010:233). Districts variations are used across socio-economic classes of social groups in this sense that it is that ingredient that constitutes the feeling or awareness of belonging to that social class, or language group and so on.

Employing the concept diastratic in a hermeneutic fashion to examine how the social variations that cut across different strata's of the South African society in a very broad sense cause underlying stresses in the transition phase of working towards a unifying nation. It also wishes to employ the meaning of the term as the ingredient that can be utilised to create a perception of the diastratically variated elements that constitute the unique nature of the South African society. In this period of social transition a tolerant attitude of openness and respectful acceptance of all the social, cultural, religious, economical and linguistic dimensions of variations present in the South African social reality is a mental and emotional disposition that needs to be cultivated so as to embrace that which is ultimately different and new. It appears that the formation of a new South African society has to take cognisance and embrace the great variety of diastratic variances present in all the different features of the South African sociological, economical, political and cultural context (Slater 2010:206). Social inequality together with social disunity is a concern in South Africa and undermines all efforts towards ethnic unity.

\section{Diversity and diastratic diversity}

Diversity, in a broad sense, refers to many demographic variables and it is very complex to define, despite the fact that the use of the term had increased in recent years. All the same, diversity is often defined as the condition of being different. Since we are all different, diversity includes everyone. Areas of diversity include, among others, race, ethnicity, religion, colour, culture, gender, nationality, sexual orientation, age, education, skills and language. Social diversity may include ethnicity, lifestyle, religious beliefs, political beliefs, heritage, and life experience. Diversity can be categorised as visible diversity as well as invisible diversity. Visible diversity is external and demonstrates things we cannot change, such as age, race, gender and other physical attributes. Invisible diversity includes attributes that are not readily seen. At face value one cannot see someone's work experience, educational achievements, income, honesty or religious beliefs. Invisible diversity is thus to be ascertained. There are combinations of diversity attributes that are both visible and invisible, which means no individual's personal diversity is exactly like another person's diversity. Diversity may be hidden or visible and it is not only skin deep. It is like an iceberg, with only a small percentage of visibility. One would not know that someone is a descendant of a landowner, a vegetarian, a Christian or an atheist, unless the person chooses to share that information. Diversity is not tolerance for difference, but ideally the inclusion of differences. Diversity is the ability for differences to coexist together, with mutual understanding or acceptance present. However, this both visible and invisible diversity requires an understanding of the various dimensions of diversity.

\section{Dimensions of diversity}

Dimensions of diversity are in a constant state of flux and not always clear-cut or easily defined. Dimensions of diversity interrelate as diversity is multidimensional and may also be concealed or obvious. Often, dimensions of diversity refer to 
specific traits that distinguish one person or groups from another. Three examples hereof are race, gender and ethnicity.

Race refers to a group of people who are perceived as physically distinctive possessing certain traits, such as skin colour, hair texture and facial features. In reality, what constitutes distinctiveness is our personal perception of differences. Within this category is also found diastratic diversity, in this sense that not all people belonging to the same race share the same economic strata, nor do they share education, language competencies, wealth and social class in equal measure.

Ethnicity refers to cultural distinctiveness. It is defined as the awareness of a cultural heritage shared with other people. An ethnic group of people's common identity is based on a shared cultural, social and ancestral heritage. Here too, people of the same ethnic groups, also fall into distinct diverse socio-economic arrangements. Their diastratic diversity varies from 'upper class' to 'working' and 'lower' socio-economic categories together with inherent subdivisions.

Gender has to do with the cultural differences that distinguish males from females. It is not to be confused with sex, which refers to biological differences, instead it is a socially constructed category. Gender also refers to the socially invented and culturally determined role that men and women play in their daily lives. In any given culture, people raise males and females to act in certain ways (Pearson n.d.:25). Gender diastratic differences are often based on social and cultural inequalities, and class-gender is another kind of social stratification since it involves power structures and economic relationships. Women do not suffer inequalities in similar manners; they suffer on different levels of intensities, because gender discrimination encompasses social division and cultural distinctions that exist between women and men. A form of gender diastratic diversity may reveal that a woman from a deprived background and poor living conditions could suffer less gender violence than a woman from a wealthy and advantaged situation. The value system often determines the quality of individual interaction, rather than socio-economic privileges.

\section{Diversity in relation to culture}

According to the lesson posted by Pearson titled Diversity: An Overview (Pearson n.d.), the concept of diversity is most often used in relation to culture. Culture is referred to as a way of life:

including everything that is learned, shared, and transmitted from one generation to the next. Although culture endures over time, it is not static. Language, values, rules, beliefs and even the material things we create are all part of one's culture. (p. 2)

The Pearson (n.d.) article affirms, however, that the influence of culture is profound on people:

As we internalize culture throughout our lives, it influences who we are, what we think, how we behave, and how we evaluate our surroundings. For example, culture shapes the way we communicate, view work, interpret conflict, define and solve problems, and resolve dilemmas. (p. 2)

Culture, the Pearson article states, is described by Geert Hofstede (2001): 'as a collective programming of the mind that reveals itself in symbols, values, and rituals'. This collective programming is often so embedded in human beings that they are hardly aware of the influence it exerts on self and others.

\section{Diastratic diversity}

All the above expressions of diversity among people assume different degrees of diversity and in turn the intensity of the diversity. This depends on the various socio-economic and cultural stratums present in a particular society, culture groups or race groups. The greatness of diversity and variations are shaped, depending on the social stratum of each person. Since human society is heterogeneous, natural differences do exist, but this is always exaggerated by social stratification differences. The stratification differences span across social layers and stratums, and these in turn span horizontally, vertically, across scales of superiority-inferiorityequality-inequality, 'lower' and 'higher' economic hierarchical positions, together with unequal power influences.

Social class refers to a person's standing in society and status is usually determined by a variety of socio-economic criteria, inter alia wealth, power, education, prestige and inherited wealth. Even though the social echelon influences where one works, lives, and goes to school, the importance thereof is not frequently addressed. This is what often determines invisible and visible differences. Often class distinctions are downplayed or disregarded, because there is a general discomfort, psychologically speaking, to acknowledge the tremendous inequality that exists in various societies. Often when we talk about social stratum we refer to lower, middle, and upper class, which have different connotations and meanings to various people. Dimensions of diversity, social class, sexual orientation, religion, personality, learning style, communication style, and family backgrounds are also diastratically variated and these variations are consistently overlooked. Even in one specific race or cultural group there exist invariable different layers of diversity. Diastratic diversity is stratification that pervades all aspects of culture and society and diastratic stratification perfuses or permeates the points of articulation between social, cultural and physical environments.

Diastratic variation is a complex social phenomenon, but in South Africa it is even more multifaceted because of the social disorder that was created by the apartheid system. Despite socio-economic differences together with the social stratification and inequalities, each constituent of the various populations has their own distinctive form of differences and inequalities. For example, a hierarchy of social inequalities exist in all population groups, ethnic groups, races, genders and cultural groups as well as within the sub-groups, but in South Africa says Jeremy Seekings and Nicoli Nattrass (2003:2) '... class inequalities are highly visible all around'. The growth 
of the black elite and 'middle class' is becoming more evident. At the same time, huge numbers of black people are confined to an 'underclass' of unemployment, poverty and social exclusion. Most white people have retained the advantages conferred by their class position at the end of apartheid by virtue of inherited wealth and profit. Nevertheless, at the same time, a significantly smaller number of white people are downwardly mobile. There is, however, a problem, says Seekings and Nattrass (2003:2) in the use of aggregate data for racial 'groups' or data on the average for racial 'groups' since both types of data obscure the social stratification within racial 'groups' and the extent to which race has ceased to be the key cause of inequality. Indeed, it might be that the emphasis on race, especially in official statistics, serves to obscure even the possibility of collecting data on other criteria, such as class (Seekings \& Nattrass 2003:2). Diastratic differences categorise differences even further in the pool of variations, and this becomes more marked in times of transition and transformation. Diastratic 'stratification' therefore refers to various social layers within numerous race and cultural groups that exist within diverse racial groups, where resources are unevenly distributed throughout the stratums because of hereditary wealth or acquired wealth or lack of wealth or loss of wealth that determines status in life.

Diastratic variety or differences encompasses a variety of other dimensions of differences, such as age, personal and corporate background, education, job function and position, geographic origin, lifestyle, sexual orientation, and personality. (Nobody is the same in these categories.) To this list can be added ancestry, national origin, creed, religion, social class, leadership style, personality, family background, marital status, military background and disability. In short, it includes whatever distinguishes us from the next person or groups of people. Learning and communication styles, personalities, and talents vary from person to person, from group to group. Likewise, everyone that is seen as belonging to a group, may not necessarily identify with that group, or they may identify with different group characteristics. The fear of diversity and in particular diastratic diversity, which is often invisible, does not make it easy to shape a diastratically integrated ethnic identity and national unity within any given state and this includes South Africa.

The task of this article is to ascertain how the Jesus Movement dealt with the heterogeneity of the Christians in antiquity. How was the multi-ethnic, multicultural, multi-lingual, multi-socio-economic strata and interracial members of the Jesus Movement assimilated and united into the Christian community despite their conditions of diastratic diversity?

Does the Jesus Movements and the early Christian communities have lessons for South Africans on how to manage diastratic diversities?

\section{The inclusive nature of early Christianity (the Jesus Movement)}

Paul of Tarsus had to deal with the diastratic diversity of the Christians in antiquity, and in particular with those in Galatia, where the problem was highly visible and pertinent. At the heart of the Galatian community was the lack of unity and in particular social unity. An original and significant factor of early Christianity was that it brought together men and women from different classes, cultures and races, something that was not part of the general practice of Hellenistic and Judaic societies of the time. As stated by Theissen (1992:214) the inclusive nature of Christianity formed the basis of 'a diastratic unity spanning different social classes, but not a representative cross section of society as a whole'. While it did not penetrate the imperial classes, nor was it equally distributed in town and country, it was drawn mostly from the lower classes. However, the diastratic cohesion in the early Christian congregations was something new in pagan society: free persons living and socialising side by side with slaves. Despite their different legal status, they were often socially on much the same level. The Christians and the Jewish congregations tried to influence the whole of everyday life with their norms and convictions. They shared meals every week, covered the whole of life, sickness, death, looking after orphans, old people, business transactions and travel arrangements. In this sense Christians of antiquity made a new 'social offer' to pagan society, namely 'diastratic solidarity' (Theissen 1992:214). Christians followed Jewish traditions in the sense that the Jewish congregations also included people from various social ranks such as Roman citizens, resident aliens without civil rights, and foreigners. This diastratic structure of Jewish and Christian congregations in fact encouraged the relativisation of status differences, economic, social and sexual differences. It is precisely in this context that the earliest Christian congregations have lessons for South Africans on how to overcome apartheid disunities and establish a new social and political order that addresses divisions (Slater 2010:248). In this sense, it is able to make a positive contribution towards the development of solidarity in South Africa by establishing measures and inculcating attitudes that cut across class and race distinctions so as to establish environmentally diastratic unity.

While the divisions of social class are not easy to overcome because of diastratic social variables, the theological attitude and practice of egalitarianism or equalism forms a favourable perspective as it advocates the fundamental equal worth, moral status and dignity of all people, regardless of their economic background. Egalitarianism theology is essentially inclusive as it counters exclusion and oppression that is socio-economically imbued.

Just as the ancient Christian Sitz im Leben had been freed from the situation which hitherto had excluded from it foreigners, slaves and women, mindful of the elements of diastratic unity, the type that was envisioned by Jesus and preached by Paul, South African Christians would be in a position to make a contribution towards the creation of a nation based on districts unity. It is therefore not by mere chance that Paul in Galatians 3:28 named the categories which were the underprivileged in social life, but who enjoyed equality in the Christian congregations that consisted of Jews and Greeks (foreigners to each other), slaves and free persons as well as 
women and men (male and female) (Gl 3:38). It is this selfdefinition of Christian equality that forms the basis of diastratic unity. As pointed out by Theissen (1992:218): even if the people of various differences had no place in the political community, they did have a place in the Ecclesia of the Lord. Here they enjoyed the freedom of the heavenly Jerusalem (Gl 4:1). The ethic of equality and freedom hitherto only accessible to the privileged was transformed by implementing the values and norms of Jesus Christ. The transformation was not merely into an internalised 'spirituality of the heart', but into the social reality of the Christian congregation. Since the Christian indicative always brings the Christian imperative and since the indicative of the good news brought the imperative, of the Christian ethic, this principle has the potential to function as an operative ethic in establishing diastratic equality and unity in all spheres of life, physically and spiritually. Not only does division contradict the truth of the Gospel of Freedom, but as a distinctive identity characteristic of Christianity, it has the potential to make a significant contribution towards transforming South African society into an egalitarian one (Slater 2010:249).

\section{Universalism and inclusiveness}

One of the pronounced characteristics of the Jewish Messianic movement, (before it was called Christianity), was universalism and inclusiveness versus Judaic exclusiveness. The significant differences between the Jewish Messianic movement and Judaism surfaced almost instantaneously at the beginning of Christianity. As one of the attributes of Judaism lays in its identity as a nation, it became apparent very soon that Christianity could not be identified with a particular race or nation, since it professed universalism and inclusiveness. Characteristic of Jesus was that he possessed a universal moral sense, his unconfined humanity and divine exaltation gave his person its ultimate significance. It was soon realised that the national Messianic idea of Judaism had a narrow and a cramping influence on Christianity. The same can be said of the apartheid regime, it constricted Christianity to sustain an unchristian ideology. The distinctive identity characteristics of the Jesus Movement become evident as it embraced universalistic traits and understandings. While Christianity affected the individual, it was also truly universal and could therefore not esteem the particularities of any one specific nation, race or religion. To be universalistic is to be all embracing: it does not exclude or separate. Once the Jesus Movement was distinguished from Judaism, it took on universalism and inclusiveness and Paul could thus express the same notion in the sentiment that in Christ there is 'neither Greek nor Jew, slave nor free ...' (G1 3:28).

The 'inclusive nature' which establish itself as an identity characteristic in nascent Christianity, formed part of a definite identity arrangement that transcends the local and the ordinary. The Gospel possesses an inner resistance to being confined to the conventional, and this was made very evident in Paul's affirmation stating that in Christ 'there is no Jew nor Greek, there is no slave nor free, there is no male and female, for you are all one in Jesus Christ' (Gl 3:28). This statement sealed 'inclusiveness' as a definite Christian identity characteristic, something the apartheid regime violated.

\section{Inclusion nullifies separation and apartheid}

The negation of the distinctions between Jews and Gentiles, male and female, slave and free as cited in Galatians 3:28 may serve for Paul as the concrete application of the initial vision for the formation of early Christianity and of the Church as expressed in Acts 2:16-18. Peter's citation from the prophet Joel at the beginning of the creation of the Church was obviously not lost on Paul. Seeing that the Spirit was poured on all people, Jews and Gentiles alike, male slaves and females alike, he declared all possible divisions null and void from the onset of the Christian Church. 1 Corinthians 12:1213 states that all believers are 'baptised into one body'. This identification of 'one body' with Christ affirms that the baptised are incorporated in the inclusion process. In 1 Corinthians 12:12-13 Paul also lists similar pairs as are found in Galatians 3:28 (except for male and female), here he also makes no distinction between 'Jews or Greeks' and 'slaves or free' in relation to how the Spirit endows people with gifts (1 Cor 12:11). In Colossians 3:9-11 there appears a similar pairings of distinction, but in addition with 'circumcised and uncircumcised', 'barbarian and Scythian'. By putting on this 'new person', becoming one in the body of Christ, the behaviour undergoes an ontological change, which forms part of the person's essential ethical character. It is thus possible that the Pauline quotation was uttered with Joel 2:28-29 as a backdrop, which advocated for the removal of distinctions between Jews and Gentiles. Joel spoke:

... And it shall come to pass afterwards, that I will pour out my spirit on all flesh; your sons and your daughters shall prophesy, your old men shall see visions. Even upon the menservants and maidservants in those days, I will pour out my spirit.

The inclusiveness, typified by Galatians (3:28), is a powerful annunciation based in Christ and in the offspring of Abraham. The statement Galatians 3:28 including 1 Corinthians 7:19; 1 Corinthians 12:13, pairs concepts that separated people and kept them divided or at enmity with each other. This is still the situation in South Africa. In this instance, Paul refers to:

- Racial differences, namely 'Greek and Jews'.

- Religious differences, the 'circumcised and the uncircumcised'.

- Cultural differences, 'barbarian and Scythian' (Col 3:9-11).

- Social differences, 'slave and free'.

- Sexual differences, 'male and female'.

While these differences are by far not the only ones that would divide humanity, they do, however, offer a representative sample and include other factors that separate humanity or place them in different camps. Paul does not erase differences between people; to the contrary, he includes the differences by stressing unity over and above disunity. The same sentiment is expressed by Matthew 25:31-46 and 1 John 4:20 who states that by being in Christ humanity forms 
one organism and for this reason human beings should be in human relationship with each other. In fact, the calling to become 'all things to all people' (1 Cor 9:22), could this amount to equality in Christ?

South African can definitely learn from the Christian concepts of inclusiveness and unity that nullify separation and apartheid.

\section{Circumcision is a cultural form of exclusion}

The demand of the Judaic Christians that the so-called full privileges of early Christianity were to be enjoyed only by those who were circumcised (Gl 1:5-11) confined Christianity to the covenanted people, that is, the circumcised people of Israel, who perceived themselves as the only legitimate children of God. Since Galatians 3:28 combated exclusivity, the early Christians would no doubt have perceived the statement as heretical. In this regard, Paul outlines that physical lineage is not a criterion when God calls, because in the new covenant when God calls through Christ (Jn 6:44) the call of the Gentiles appears to be just as valid as that of an Israelite. According to Galatians (1:11-19; 2:1-14), Paul counters what he calls the 'evil influences of the Judaizers in Galatia' (Gl 3:4:31), showing that this doctrine of cultural exclusivity is destroying the very essence of Christianity, and by so doing is lowering the spirituality of Christ to an outwards ceremonial system. Christianity in antiquity, as proposed by Paul's writing to the Galatians, made no provision for racial exclusiveness epitomised by the statement that 'in Christ there is no Jew or Greek', Paul's principle of Christian- or even human- inclusiveness is based on the new principle of baptism. He argues that by means of baptism, Jesus Christ had introduced a radically new departure from the Old Testament where only the male person through circumcision was regarded as the direct carrier of the covenant. In the new dispensation offered by Jesus Christ, both men and women share equally in Christ and so become equal members or participants of the Kingdom of Jesus Christ. Characteristic therefore of Christianity in antiquity, and reinforced in Paul's letter to the Galatians, the inequality of the differences between Greek and Jews, circumcised and the uncircumcised, 'slave and free'; and 'male and female' is of no avail in Christianity; to the contrary it was a matter of inclusions. Inclusiveness based on God's impartiality, incorporates all of humanity as full participants in the body of Christ.

Cultural exclusions in South Africa are still pervasive. This is apparent in the xenophobic attacks, gender violence and the prevailing economic discrepancies. Such exclusivities are divisive as they violate people's human rights and dignity.

\section{Inclusions do not imply the removal of differences}

Inclusions, however, do not necessarily imply the removal of differences; instead Paul also argues for differences to be accommodated within Christianity. The negation of differences should not be equated with the removal of differences between Jews and Gentiles, male and female, free and slave, circumcised and uncircumcised. His argument is that becoming a follower of Christ does not result in undifferentiated humanity as differences will always remain, but within Christ they are of no avail (Gl 5:6; 6:15; 1 Cor 7:19). These differences are irrelevant to becoming a Christian, and such distinctions and categories are inappropriate to entering the body of Christ. The prime factor for Paul is not to remove differences, but to emphasise that these differences are not of importance to be included in the body of Christ. What underlies the assertion here $(\mathrm{Rm} 10: 12)$ is the recognition that 'God shows no partiality' (Rm 2:11; 10:11-13). This appeal to inclusiveness is also evident in Luke's description of Peter's encounter with Cornelius when he was persuaded to preach the Gospel to the Gentiles (Ac 10:24, 38; 11:9-12). Although this characteristic of inclusiveness is portrayed by God's impartiality, it has at the same time implications for how the participants in Christ relate to each other within the then emerging Christianity. The attitude of inclusions played a strong and important role in emerging Pauline Christianity as this radical negation of partiality he describes as a 'new creation' or a 'new person'. This 'new creation' does not refer to an alteration in the physical nature of believers, or to the inward individual change at the level of what it means to be human, but rather to be the 'renewed people' of God. Inclusiveness is a prescribed recipe for national unity and identity, preceded by conversion, renewal and forgiveness.

Identity and nation building in South Africa, if it embraces Christian principles, include and accept differences and diversity. In a culture of inclusion the practice of reciprocal recognition of diverse cultures is mandatory. As diversity includes multiplicity in terms of cultural background, religion, beliefs, gender and value systems, it is essential that any possible boundaries imposed on people have to be transformed and transcended by exercising mutual recognition, reciprocal understanding, mutual enabling, trust and integrity. These values are not culturally bound.

\section{Inclusiveness not the same as equality}

Another point of value is that inclusiveness may not be the same as equality and does not carry similar associations in the Galatians 3:28 contexts. Nevertheless, the so-called assertion that Galatians 3:28 proclaims the equality of men and women, free and slave, circumcised and uncircumcised was most likely an uncommon concept and whether early Christianity recognised and practised equal worth or even equal authority of masters and slave, male and female is hard to discern. It is possible that the first century's claim to equal status in salvation may not necessarily have translated to equal claim to social, political or religious status. What is clear is that Galatians 3:28 is intricately woven into the fabric of Paul's epistles; its meaning and significance cannot be detached from the larger tapestry of the New Testament. Characteristic of early Christianity as expressed by Paul in Galatians is that being 'baptised into Christ' highlights an incorporation process and makes no distinction regarding the differences between 'Jews and Greeks', 'slave and free' and 'male and female': 
- Neither slave and free, equals social equality.

- Neither male nor female, equals gender equality.

- Neither Jews and Greeks, equals racial equality.

- Neither circumcised and uncircumcised, equals religious equality.

- Neither barbarian and Scythian, equals cultural equality.

Galatians 3:28 embodies a shift from an old world to a new creation characterised by Christ. However, the inclusiveness of Christianity involves becoming like Christ, finding one's identity in Christ, no longer in Judaism, which was the old identity. The new identity was found in Christ and all are welcome in the new inclusive creation.

For South Africans, in the effort of building a new identity, implies nullifying the old that caused divisions and separation. It implies egalitarianism, despite differences. Radical egalitarianism or equalitarianism holds that all human beings are equal despite differences. However, to define full equality without differences is almost an anomaly as it implies obliterating human variations. There is a perception that equality among humans (concerning their being and worth) is only ontological as it is a biblical teaching that claims that all human beings - male and female - have equal standing before God as created beings in need of salvation. This understanding is borne out of the Genesis statement that both 'male and female' were created in the Image of God (Gn 1:27; Mt 19:4; Mk 10:6). Both male and female were redeemed by Jesus Christ, so that in Christ, both male and female are joint heirs of the grace of life (1 Pt 3:7).

\section{Does equality mean equal in all respects?}

The questions are: does Galatians 3:28 refers to equality, and what is meant by full equality? What are the standards of comparison whereby one measures equality since things and people in life are both equal and unequal? Aristotle said that the worst form of equality is to try and make unequal things equal. It is clear that Galatians 3:28 cannot be coerced into the ambiguousness of equality. Is there a difference between biblical equality and other equality such as social or political equality? What is the nature of the equality that is taught by the polar opposites or couplets of Galatians 3:28? Both Jews/ Greek, male/female, slave/free, circumcised/uncircumcised are 'equally justified by faith' (v.24), equally free from bondage of legalism (v.25), equally children of God (v.26), equally clothed with Christ (v.27), equally possessed by Christ (v.28), and equally heirs of the promises to Abraham (v.29).

The couplets capture the totality of humanity from a salvation-historical perspective since Scripture describes the Gospel promise as coming first from the Jews and to the Gentiles. From the ancient Roman perspective all people were either 'slave or free'. This was a legal distinction for dividing all people. The 'male or female' couplet divides humanity according to their basic sexual identity granted to them at creation. Regardless of how people are viewed, be it from a salvation-historical perspective, or a legal perspective, or from a creation perspective, they all share the same privilege of covenantal union with God in Christ and they do so in equal measure.

The exegetical understanding and implication of Galatians 3:28-29 implies a new vertical relationship with God resulting in a new equal horizontal relationship with people. All inequalities, as stated by Hansen (1994:112), racial, economic and gender barriers are removed in Christ as equality and unity of all in Christ are part of the essence of the Gospel.

Equality in Christ implies inclusiveness, unity and justness in Christ. Paul was of strong opinion that racial equality between Jews and Gentiles was to be an experienced reality within the early Christian community. The expression of racial superiority of one group over another was a violation of the essence of the Gospel of Jesus Christ. Any expression of racial superiority, gender superiority (men over women), social superiority (slave over free) articulated then and now violates the truth of the Gospel. Paul is of the opinion that all divisions and prejudices had been abolished in Christ (Hansen 1994:112).

Paul argues that Gentiles do not have to become Jews to be fully accepted by Jewish Christians and in so doing become fully part of the life of the followers of Christ. In the same vein today, black people do not have to become white or females do not have to become males or vice versa for full participation in the South African society. By faith in Jesus Christ the Gentile, the slave and the woman have been included in the full realm and inheritance of Christ. No restriction is implied in Paul's equalising of the status of all people regardless of race, socio-economic, gender or educational status.

\section{Lessons for South Africa}

South African people as a whole have to build a diverse culture of inclusion. Diversity is a cultural question of norms, values, beliefs and expectations. Coping with diversity on a normative level means recognising differences while looking for the common bond (Pless \& Maak 2004:131). To build a diverse culture of inclusion Nielsen and Kepinski (2014) advise that we need to focus on raising unconscious bias awareness. In this regard, they assert that: 'brain researchers estimate that the unconscious system of the brain controls about $80-90 \%$ of our responses and actions' (Nielsen \& Kepinski 2014:n.p.), and unconscious implicit associations limit our perception. To illustrate this they use the following example: often when we hear the word 'leader' we implicitly linked it with White Western men, and consequently struggle to picture leaders beyond this view. These types of connections are apparently unconsciously embedded and affect our behaviours much more than we think. According to their estimation that in creating a diverse and inclusive culture, the unconscious brain is one of the biggest challenges in the 21st century. The so-called argument that 'time will change the status quo' or a belief that 'with the next generation, 
diversity and inclusion will no longer be an issue' are no longer valid. Nielsen and Kepinski (2014) says that research clearly shows that the unconscious system of the brain has not evolved much, and certainly not kept pace with the dynamics in our current complex, global society. In the effort to outsmart the brain, Nielsen and Kepinski (2014) maintain that the inclusion Nudge is what enables the brain to feel the need for change rather than having only a rational understanding of the need for inclusive behaviour. This implies tapping into feelings by means of so-called eyeopening experiences. The intent of this type of inclusion Nudge is to make people (the brain) perceive an issue differently by altering the frame or the anchor of a thought process. This is about creating a new discourse and changing all the connotations of the words associated with inclusion, diversity, gender, equality et cetera. New kinds of questions need to be asked to initiate a new kind of thought process that will help promote inclusiveness as 'a need to have' and not 'a nice to have' (Nielsen \& Kepinski 2014).

To build an inclusive identity it is therefore necessary to take cognisance of profound distinctions within the South African society. The diastratic differences pertaining to racial, cultural, social, economic, sexual and gender lose importance if inclusivity forms part of the creation of a new national identity build on the values of unconditional acceptance. As indicated by Dunn (1993:207) it was not Paul's intention to have all distinctions removed. In early Christianity, Jews remained Jews (Gl 2:15) and slaves did not cease to be slaves (1 Cor 5:21). The same holds for the new South African social identity: distinctions and differences remain and cannot be obliterated. The value of diversity starts with guaranteeing the same rights to everyone (Pless \& Maak 2004:132). People need to feel recognised as different, but equal. While legal and political recognitions are moral essentials, it is practiced solidarity, the face-to-face recognition of equals that unleash solidarity and unity and thus identity. Pless and Maak (2004:133) claim that: 'For an inclusive diversity culture this also means that respect is paid to the plurality of sub-cultures ...' so that none is excluded from the ongoing moral discourse in shaping a new cultural reality.

The character of unity or oneness in South Africa is then not so much the eradication of all racial, social or gender differences, but an integration of such differences into a common inclusiveness ('in Christ') and before the law.

This article, therefore, proposes 'inclusion' as a principal identity characteristic of nascent Christianity, to be reappraised in the South African context. While egalitarianism holds that all human beings are equal and rightly protests against the exploitation resulting from human differences, the philosophy of 'inclusions' solicits an inherent significance for equality and egalitarianism. According to John Riches (2008:210), the call to human oneness is a stirring call for equality. To promote the oneness in Christ: does not necessarily amount to unqualified equality. Paul's strong identification of himself as a Jew and his equally powerful identification of himself as a Christian, is exactly the application that is necessary in South Africa. There is nothing wrong to have a strong identification of one's race or tribe, as long as it is not a cause of division. The common denominator, which is to be human and a South African, should be the source of unity, oneness and inclusiveness. The pairs of opposites in Galatians 3:28 represent the building blocks of the old world, which is being replaced by God's action in establishing a new creation. The same holds in the South African scenario, the (apartheid) regime, is identified as the 'old things' that has now passed on to make place for the new creation (2 Cor 5:17).

Inclusiveness is all-encompassing and relativises diastratic variations that categorise people. Hansen (1994:14) alleges that whatever ethnic rivalries are destroying societies, the letter to the Galatians calls Christians to express the truth of the Gospel of communities where divisions are of no value. South Africans ought to extract what is essential and collective and allow these qualities to take its course in establishing interconnectedness. In this sense South Africa requires renewed awareness and consciousness of Christian identity characteristics. Inclusiveness and universal consciousness possess the instrumental value to remove the long-established wedges that still form national and social boundaries between people in everyday life. Paul was exceedingly conscious of the inclusiveness in the Spirit; of freedom; of reconciling humanity with God and of God's union with humanity through Jesus Christ. Inclusiveness can only carry positive conclusions for the people of South Africa. In antiquity Paul's message also occurred during a cultural, religious and social transition: a transition from the allexclusive Jewish faith environment to an all-inclusive Jewish and Gentile faith amalgamation.

\section{The Bill of Human Rights is a transformative tool and human equaliser}

As a tool, human rights are not exclusive, selective or particular, it is universal in nature, and applies in equal measure to all. The application of the Bill of Rights is both vertical and horizontal: a human equaliser and Section 39 states that the values that underlie an open and democratic society are based on human dignity, equality and freedom. There exists an intimate link between human rights and human dignity which cannot be separated, although argued by Jack Donnelly (1982:303) that human rights are but one way that has been devised to realise and protect human dignity.

'Everyone has inherent dignity and the right to have their dignity respected and protected'. This right is enshrined in the South African Constitution in Section 10. The importance of dignity, as a founding value of the new Constitution, cannot be over-emphasised. Recognising a right to dignity is an acknowledgement of the intrinsic worth of human beings. This right, therefore, is the foundation of many other rights. Respect for the dignity of all human beings is particularly important in South Africa since apartheid was a denial of a common humanity and the dignity of each person. Human 
rights are there to protect human dignity and the Christian notion of Imago Dei roots the dignity of each person in being created in the Image of God (Donnelly 2014:20). Human dignity is therefore regarded as the 'Ultimate Value' that provides coherence to human rights (Hasson 2003:83). The Universal Declaration of Human Rights (1948) states that:

recognition of the inherent dignity and of the equal and inalienable rights of all members of the human family is the foundation of freedom, justice and peace in the world. (n.p.)

Human dignity is foundational to a person's right to freedom, to physical integrity and to equality and in this sense it is both a foundational value and a protected human right.

Human rights overlook diastratic variations and do not discriminate between socio-economic or any other differences. The significance of human rights is universal and allencompassing. South Africans need to only make a concerted effort to embrace the inherent values of human rights as this is a legitimate and uncomplicated way to realise and integrate equality, value and respect diversity, and dismiss the difference of people in the formation of a national identity.

\section{Conclusion}

Despite the fact that inclusiveness and equality are the underlying guiding principles of building the new South African society, exclusivity and inequality (as we understand it) still remain very harsh realities. This is not confined to tensions between black and white, rich and poor; it is also a harsh reality between black and black, between local and foreigner, between male and female, rich and poor. The intensity thereof could be as a result of diastratic variations of exclusivity and inequality. Despite the fact that much credit can be given to the new dispensation, old divisions had not been eradicated and regrettably new prejudices and divisions have surfaced such as xenophobia, homophobia, materialism, criminal violence and new-found racial intolerance.

The formation of a diastratically integrated South African identity requires the all-encompassing recognition of the various ethnic varieties. The various cultural values can alone intersect when the dignity and differences of each person are respected and appreciated. Inclusive diversity consciousness can help in the formation of a common South African identity. This can be done by the cultivation of a state of mind that is fully aware and sensitive to diversity and differences. Diversity consciousness requires the activity of both mind and senses and it implies developing an understanding as well as an awareness of diversity. Diversity consciousness has to be taught by means of diversity education. Diversity skills can be developed, which include awareness, understanding, flexible thinking, communication, teamwork, leadership skills and the ability to overcome personal and social barriers. Diversity consciousness provides greater insight and heightens tolerant awareness for human differences.

To create a culture of inclusion can, according to Pless and Mark (2004:141), be brought into the existence by people who buy into the idea, who share the desired values in terms of diversity, who feel comfortable with diverse environments and are committed to bring this vision to life. The people are generally the most important investment for any value-based country. Ongoing dialogue is crucial to develop trusting relationships that lead to behaviour changes.

In this article, I have tried to show that by using the tenets of Christianity in antiquity, is also an attempt to make and keep Christianity authentic and relevant to South Africa. If this is not done, the real danger exists that the Christian faith will forfeit relevance in the process of transformation. It is well to realise that Christianity is not a culture nor a monolithic institution, but a personal message, which encounters persons - not superficially, but concretely in life situations (Magesa in Okure \& Van Thiel 1990:113). I am of opinion that it is by hearing the personal message, by encountering Christ, that the stage is set for change by recognising the value and importance of a culture of inclusion.

\section{Acknowledgements Competing interests}

The author declares that she has no financial or personal relationships which may have inappropriately influenced her in writing this article.

\section{References}

Auer, P. \& Jurgen, E.S., 2010, Language and space: An international handbook of linguistic variation. Theories and methods, Mouton de Gruyter, Berlin.

Donnelly, J., 2014, 'Human dignity and human rights: Swiss initiative to commemorate the 60th anniversary of the UDHR - Protecting dignity: An agenda for human rights - Research project on human dignity', [O], viewed 12 September 2014, from http://www.udhr60.ch/report/donnelly-HumanDignity_0609.pdf

Donnelly, J., 1982, 'Human rights and human dignity: An analytic critique of nonWestern conceptions of human rights', The American Political Science Review, 76 303-316.

Donnelly, J., 2009, 'Human dignity and human rights', viewed June 2009, from http:// www.jstor.org/stable/23254746

Dunn, J.D.G., 1993, Theology of Paul's letter to the Galatians, Cambridge University Press, Cambridge.

Hansen, G.W., 1994, Galatians, Intervarsity Press, Downers Grove, IL.

Hansen, G.W., 1996, What is Christianity? Intervarsity Press, Downers Grove, IL.

Hasson, K.J., 2003, 'Religious liberty and human dignity: A tale of two declarations', Harvard Journal of Law and Public Policy, 27, 81.

Hofstede, G., 2001, Culture's consequences: Comparing values, behaviors, institutions and organizations across Nations, 2 nd edn., Sage, Thousand Oaks, CA.

Magesa, L., (in Okure, T. \& Van Thiel, P), 1990, Articles evaluating inculturation of Christianity in Africa, Amecea Gaba Publications, Eldoret, Kenya.

Nielsen, T.C. \& Kepinski, L., 2014, Nudging the unconscious mind: Practical tips for inclusive behaviour, in Charta der Vielfalt, Unternehmensinitiative für Diversity und Diversity Management.

Pearson, n.d., 'Diversity: An overview', Pearson, viewed 19 Dec. 2012, from http:// www.pearsonhighered.com/assets/hip/us/hip us pearsonhighered/ samplechapter/0135014638.pdf1. M01_BUCH4639_03_SE_C01.QXD

Pless, N.M. \& Maak, T., 2004, 'Building an inclusive diversity culture: Principles, processes and practice', Journal of Business Ethics 54(2), 129-147.

Riches, J., 2008, Galatians throughout the centuries: Blackwell Bible Commentaries, Blackwell, Oxford.

Seekings, J., 2003, Class, race and inequality in South Africa (Yale U.P., New Haven, CT, 2005; University of KwaZulu-Natal Press, Pietermaritzburg, 2006) (co-authored with Nicoli Nattrass).

Slater, J., 2010, Christian identity characteristics in Paul's letter to the members of the Jesus-Movement in Galatians, AuthorHouse, Bloomington, IL.

Theissen, G., 1992, Social reality and the early Christians: Theology, ethics and the world of the New Testament, Fortress Press, Minneapolis, MN.

United Nations, 1948, Universal Declaration of Human Rights, United Nations. 